\title{
Realizing productive capacity of crested wheatgrass varieties in the southern forest- steppe of the Bashkortostan Republic
}

\author{
Asiya Nizaieva, ${ }^{1, *}$, Rifkat Akchurin ${ }^{1}$, Rifkhat Biktimirov ${ }^{1}$, Rasul Musin ${ }^{1}$, and Leonid \\ Malyshev $^{2}$ \\ ${ }^{1}$ Bashkir Agricultural Research Institute - a separate structural division of the Ufa Federal Research \\ Center of the Russian Science Academy, Ufa, Russia \\ ${ }^{2}$ Federal Research Center All-Russian Institute of Plant Genetic Resources named after N.I. Vavilov, \\ Saint Petersburg, Russia
}

\begin{abstract}
Crested wheatgrass being high drought-resistant, is a promising forage crop for the Republic of Bashkortostan. It is relevant in developing varieties adapted to the environmental stress factors that have productive longevity, increased seed and fodder productivity. The paper presents the research results of crested wheatgrass varieties conducted in the nursery of competitive variety testing for seed productivity in 2018-2020. High seed productivity due to well-developed tillering capacity, powerful heads and large seeds of cultivars like Batyr, Brodskii crested, Parkway indicate their adaptation to local conditions and make them promising varieties for further study.
\end{abstract}

\section{Introduction}

Perennial grasses are a major component of forage lands. They provide high-quality feed thanks to high and stable fodder and seed productivity, longevity and winter hardiness. Perennial grasses are essential in protecting soils from water and wind erosion $[1,2,3]$. A significant reserve for increasing fodder supply is expanding the range of forage plants, replacing low-yielding species with more productive ones of enhanced nutritive values adapted to the soil and climatic conditions of cultivation [3, 4]. Since the agricultural production of the Republic of Bashkortostan develops in different climatic zones and is cyclically exposed to severe drought, crested wheatgrass, characterized by high drought resistance, is of particular interest. In the arid zone, it can be considered the most important component of alfalfa-cereal mixtures. Crested wheatgrass has high nutritive values. $100 \mathrm{~kg}$ of hay contains 48.7 fodder units and $6.9 \mathrm{~kg}$ of digestible protein; $100 \mathrm{~kg}$ of green crop mown during the earing period consists of 22.7 feed units and $4.1 \mathrm{~kg}$ of digestible protein. It reaches matureness in the second or third year after sowing. It stays long in the grass stand and often displaces other plants. Of the 13 wheatgrass species known in Russia, four species have been cultivated: crested (Agropyron pectinoforme Roem. et Schult), crested (A. cristatum L. Gaerth); desert (A. desertorum Fisch) and Siberian (A. sibiricum) [5]. The most common

\footnotetext{
${ }^{*}$ Corresponding author: nizaeva_a@mail.ru
} 
crested wheatgrass is a drought-resistant, winter-hardy and salt-tolerant plant. It is good for long-term hay fields and pasture lands. Wheatgrass can resist prolonged drought, has perfect frost and winter hardiness [6]. It is a single-cut plant with a good aftergrowth at early mowing. It has the highest yield of hay and seeds in the second year of life. Crested wheatgrass is an important component in grass mixtures with legumes in field crop rotations. High drought resistance, good vegetative and especially pronounced ability to seed renewal provide longevity to crested wheatgrass stand. The yield of dry weight is $15-25 \mathrm{c} / \mathrm{ha}$. Crested wheatgrass is distinguished by its high forage qualities among perennial grasses. It contains $3.0-7.2 \%$ protein, $1.0-4.7$ fat, $8.9-16.1$ fiber, 14.2-21.6 nitrogen-free extracts, $2.2-3.0 \%$ ash at the earing phase at a humidity of $8.8-12.2 \%[7,8]$. Only one variety of crested wheat, Brodskii crested, is approved for cultivation in the Ural region, including the Republic of Bashkortostan. The practice of many countries proves the advantage of selection work in the natural and climatic zone of the variety use [9]. The given paper aims to study and identify the best crested wheatgrass cultivars adapted for cultivation in the southern forest-steppe zone of the Bashkortostan Republic.

\section{Materials and methods}

7 varieties of crested wheatgrass were studied in nurseries of competitive variety testing in the scientific division "Ufimskoe" of the Bashkir Agricultural Research Institute of the Ural Federal Research Center of the Russian Science Academy, located in the southern foreststeppe of the Republic of Bashkortostan. The soil was tilled to a depth of $25 \mathrm{~cm}$, ploughed in the early spring, cultivated and harrowed, rammed before and after sowing. The seeding rate is $7 \mathrm{~kg} / \mathrm{ha}$. The sowing depth is $2-3 \mathrm{~cm}$. Sowing was carried out with a SN-16 seeder, row spacing was $60 \mathrm{~cm}$. The registered area of plots is $50 \mathrm{~m}^{2}$, the number of replications is fourfold. The agrochemical properties of typical chernozem were characterized by the following indicators: the humus content (according to Tyurin) $-8.5 \%$, mobile potassium and phosphorus (according to Kirsanov) - $128 \mathrm{mg} / \mathrm{kg}$ and $109 \mathrm{mg} / \mathrm{kg}$ of soil, respectively. The soil reaction is slightly acidic. The research targets were crested wheatgrass varieties Batyr, Kazakhstanskii 2, Iubileinyi 30 (Kazakhstan), Brodskii crested (Orenburg region), Pavlovskii 12 (Voronezh Region), Ongudaiskii (Altai Territory), Donetskii crested (Ukraine), Parkway, Fairway (Canada), provided by the All-Russian Institute of Crop Production. According to the weather station Ufa-Dema, the average annual precipitation for the growing season in the conditions of the southern forest-steppe, where studies were conducted (May +1 st decade of September) was $278 \mathrm{~mm}$, the average daily air temperature $+15.2^{0} \mathrm{C}$, the hydrothermal index (HTI) -1.22 . The research years differed in the meteorological conditions of the plant growing season. The weather conditions in 2018 favoured the development of a high yield of crested wheatgrass seeds. Wheatgrass bloomed in mid-June. During the flowering period, the weather was hot and dry, which was crucial for pollination and seed setting. The average daily temperature was $21.4^{\circ} \mathrm{C}$. The HTI for the growing season was 1.0 . The weather conditions in 2019 were characterized by sufficient precipitation and a relatively low air temperature (HTI - 1.3). The weather in June was also cool. The wheatgrass flowering was delayed. The average daily air temperature for decades was lower by $1-2^{\circ} \mathrm{C}$. The total monthly precipitation was $86 \mathrm{~mm}$, being $14 \mathrm{~mm}$ higher than the long-term annual average. The growing season in 2020 was uneven in heat and moisture, HTI -1.1. In May, precipitation was limited with $11 \mathrm{~mm}$ against mean rainfall of $47 \mathrm{~mm}$; the temperature was $15.4^{0} \mathrm{C}$. In June, the lack of precipitation and moderate temperature conditions persisted $(13 \mathrm{~mm}$ and $+17.1^{\circ} \mathrm{C}$, with the long-term annual average of $67 \mathrm{~mm}$ and $+18.1{ }^{\circ} \mathrm{C}$ ).

The main research method was a field experiment, accompanied by laboratory analyses, records and observations. The objectives of the current work were addressed records, observations, and analyses according to the All-Russian Fodder Research Institute's 
"Methodological guidelines for conducting research in the seed production of perennial grasses" (Moscow, 1986), "Methodological guidelines for the selection and primary seed production of perennial grasses" (Moscow, 1993) and the methodology of the State Commission for Variety Testing of Agricultural Crops (Moscow, 1985). Statistical processing of the experimental data was carried out according to B.A. Dospekhov (1978) by the one-way analysis of variance.

\section{The results and discussion}

The main characteristics of crested wheatgrass seed productivity are the number of generative shoots, the spike length and width, the number of seeds in the spike, the weight of 1000 seeds (Table 1). Depending on the weather conditions during the growing season, these signs can have a wide range of variation [10].

Table 1. Seed productivity of crested wheatgrass varieties.

\begin{tabular}{|c|c|c|c|c|c|c|}
\hline Varieties & $\begin{array}{c}\text { Catalogue } \\
\text { number }\end{array}$ & $\begin{array}{c}\text { The number of } \\
\text { reproductive } \\
\text { shoots, pcs/m }\end{array}$ & $\begin{array}{c}\text { Spike } \\
\text { length, } \\
\mathrm{cm}\end{array}$ & $\begin{array}{c}\text { Spike } \\
\text { width, } \\
\mathrm{cm}\end{array}$ & $\begin{array}{c}\text { The number } \\
\text { of spikelets } \\
\text { ina spike, pcs }\end{array}$ & $\begin{array}{c}\text { Thousand } \\
\text {-seed } \\
\text { weight, g }\end{array}$ \\
\hline $\begin{array}{c}\text { Chishminskii } \\
\text { crested 6 st }\end{array}$ & 172 & 5.3 & 1.4 & 26 & 1.91 \\
\hline Brodskii crested & 29811 & 221 & 6.2 & 2.0 & 32 & 2.22 \\
\hline Kazakhstanskii 2 & 43080 & 157 & 6.1 & 1.3 & 26 & 1.77 \\
\hline Pavlovskii 12 & 27880 & 186 & 5.8 & 2.0 & 24 & 1.82 \\
\hline Donetskii crested & 38873 & 171 & 5.7 & 1.8 & 24 & 1.83 \\
\hline Iubileinyi 30 & 38243 & 165 & 5.8 & 1.5 & 26 & 1.85 \\
\hline Batyr & 47346 & 232 & 6.0 & 2.0 & 28 & 2.25 \\
\hline Ongudaiskii & 47596 & 201 & 5.2 & 1.8 & 26 & 1.94 \\
\hline Parkway & 36266 & 195 & 6.1 & 2.0 & 28 & 2.16 \\
\hline Fairway & 33394 & 178 & 6.2 & 1.6 & 30 & 1.78 \\
\hline HCP 05 & & 17,5 & 0.26 & 0.19 & 1.8 & 0.13 \\
\hline
\end{tabular}

The seed material quality depends on the thousand-seed weight to a certain extent. Large, filled seeds contain more nutrients, they produce well-developed plants with greater productivity of green crop and seeds. During the research, three cultivars had the highest thousand-seed weight: Batyr $-2.25 \mathrm{~g}(+0.34 \mathrm{~g}$ to the standard); Brodskii crested $-2.22 \mathrm{~g}$ $(+0.31 \mathrm{~g})$; Parkway $-2.16 \mathrm{~g}(+0.25 \mathrm{~g})$. The number of spikelets per spike is one of the main indicators of yield. It varied from 24 to 32 pieces. Correlation analysis of seed productivity distinguished two pleiades of traits:

1. The number of generative shoots, the spike width and the weight of 1000 seeds

2. The spike length and the number of spikelets in the ear.

Table 2. Correlation structure of seed productivity elements.

\begin{tabular}{|c|c|c|c|c|c|c|}
\hline Characteristics & Abbr & NG & LS & BS & NSPT & W1000 \\
\hline The number of reproductive shoots & NG & 1.000 & 0.163 & $\mathbf{0 . 7 8 8}^{*}$ & 0.537 & $\mathbf{0 . 8 7 9 *}$ \\
\hline Spike length & LS & 0.163 & 1.000 & 0.200 & $\mathbf{0 . 5 8 9} * *$ & 0.244 \\
\hline Spike width & BS & $\mathbf{0 . 7 8 8} *$ & 0.200 & 1.000 & 0.226 & $\mathbf{0 . 6 6 4} *$ \\
\hline The number of spikelets in a spike & NSPT & 0.537 & $\mathbf{0 . 5 8 9 * *}$ & 0.226 & 1.000 & 0.572 \\
\hline Thousand-seed weight & W1000 & $\mathbf{0 . 8 7 9} *$ & 0.244 & $\mathbf{0 . 6 6 4}^{*}$ & 0.572 & 1.000 \\
\hline
\end{tabular}

$*$ - reliable at $\mathrm{p}=0.05$

$* *$ - reliable at $\mathrm{p}=0.07$ 
The relationship between the thousand-seed weight and the spike width of crested wheatgrass is most pronounced with the number of generative shoots, where the correlation coefficient is 0.879 and 0.788 . High correlations are also observed between the spike length and the number of spikelets in the ear -0.589 , the spike width and the weight of 1000 seeds 0.664 (Table 2). Factor analysis of the correlation matrix made it possible to construct new "traits" - factors corresponding to the selected pleiades: Factor 1, describing the power of plant development, and Factor 2, associated with the linear size of the ear (Table 3). The analysis of variability between traits will be of great importance for planning a successful breeding program [11].

Table 3. Variability structure of seed productivity traits.

\begin{tabular}{|l|c|c|}
\hline & Factor 1 & Factor 2 \\
\hline The number of reproductive shoots & $\mathbf{0 . 9 5 2}$ & 0.197 \\
\hline Spike length & 0.021 & $\mathbf{0 . 9 0 8}$ \\
\hline Spike width & $\mathbf{0 . 8 8 0}$ & 0.034 \\
\hline The number of spikelets in a spike & 0.357 & $\mathbf{0 . 8 3 1}$ \\
\hline Thousand-seed weight & $\mathbf{0 . 8 8 0}$ & 0.299 \\
\hline Variation rate & 51.6 & 32.9 \\
\hline
\end{tabular}

According to the factor values, the varieties are differentiated into three groups:

1. With high tilling capacity, a powerful ear and large seeds-Batyr, Brodskii crested, Parkway.

2. With medium tilling capacity, a wide short spike and medium-weight seeds - Iubileinyi 30, Kazakhstanskii 2 and Fairway.

3. With low tilling capacity, a narrow long spike and small seeds - Ongudaiskii, Pavlovskii 12, Donetskii crested, Chishminskii crested 6 (Fig. 1).

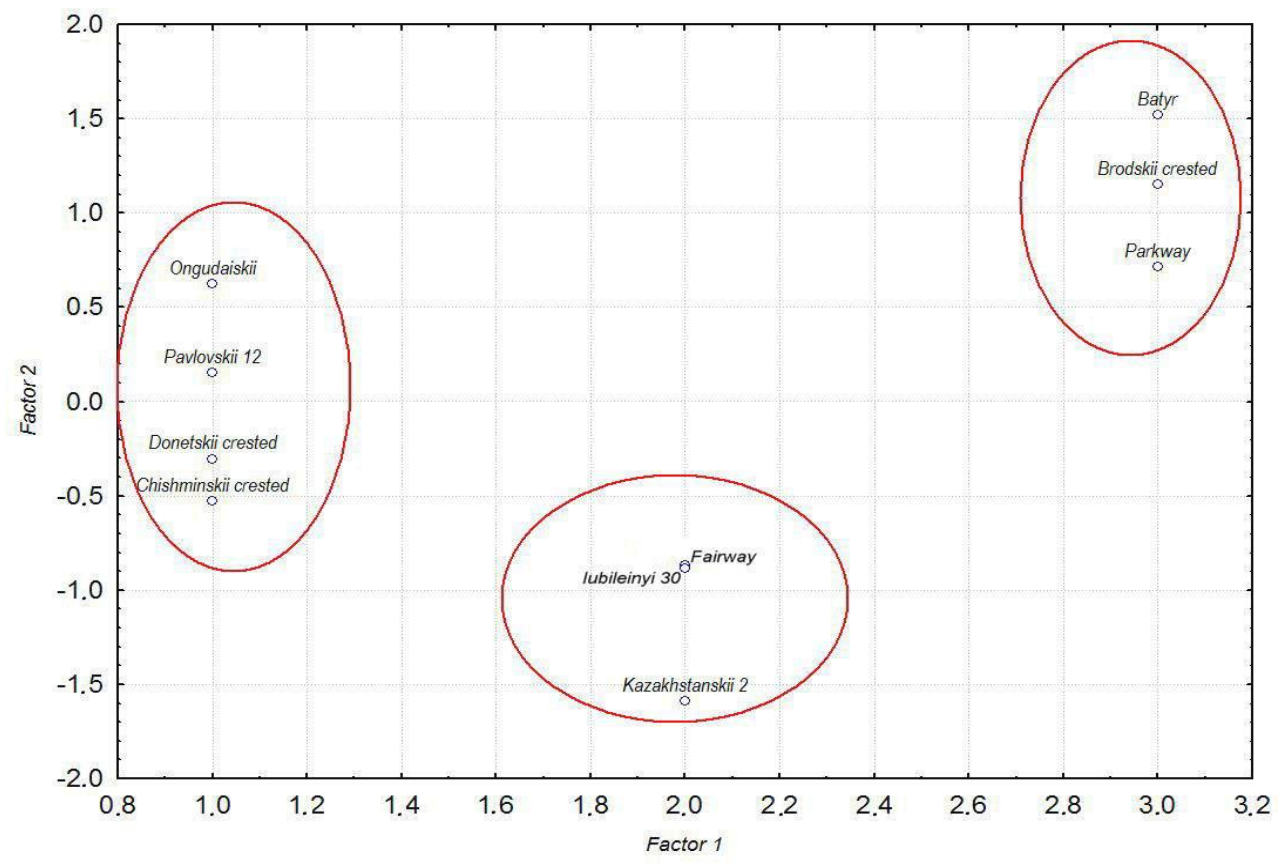

Fig. 1. Grouping by the seed productivity structure. 
The study of crested wheatgrass variety seed productivity revealed an advantage of five cultivars: Batyr $4.48 \mathrm{c} /$ ha $(+42.03 \%$ to the standard), Brodskii crested $4.08 \mathrm{c} /$ ha $(+29.3 \%)$, Ongudaiskii $-3.92 \mathrm{c} / \mathrm{ha}(+24.29 \%)$, Parkway $-3.65 \mathrm{c} /$ ha $(+15.73 \%)$ and Donetskii crested $3.52 \mathrm{c} /$ ha $(+11.4 \%)$ over the local variety Chishminsky crested 6 , used as a standard. The seed productivity of the studied cultivars depended on the weather conditions during flowering and pollination. The observations showed that the optimum air temperature for seed pollination and development is $25-28^{\circ} \mathrm{C}$. The Fairway variety formed a seed yield below the standard by $0.02 \mathrm{c} /$ ha (Fig. 2).

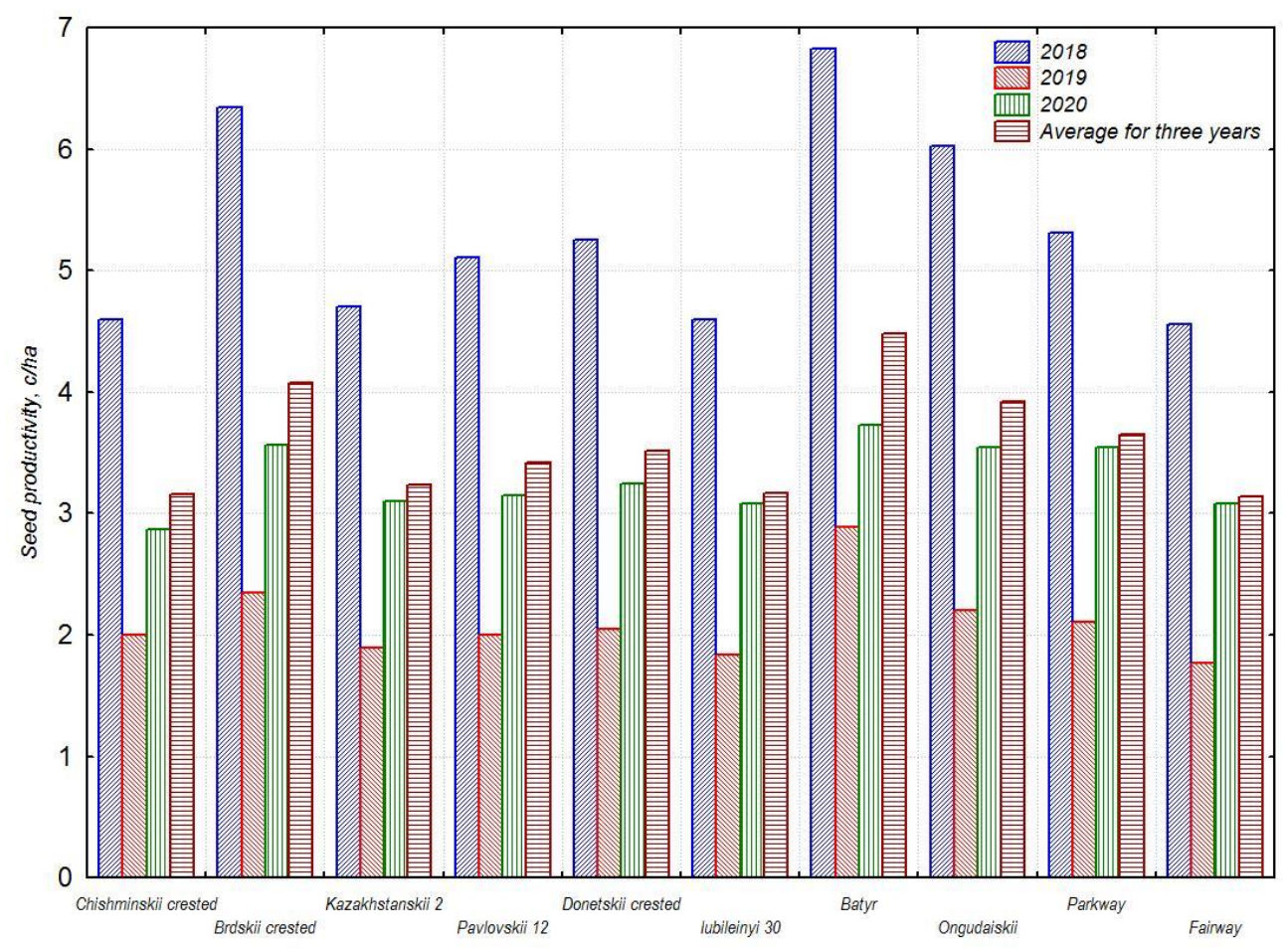

Fig. 2. Seed productivity of crested wheatgrass varieties.

\section{Conclusion}

The conducted research revealed cultivars with high seed productivity. The maximum seed yield was developed under different weather conditions by Batyr $4.48 \mathrm{c} / \mathrm{ha}(+42.03 \%$ to the standard), Brodskii crested 4.08 c/ha (+29.3\%), Ongudaiskii -3.92 c/ha (+24.29\%), Parkway $-3.65 \mathrm{c} / \mathrm{ha}(+15.73 \%)$ and Donetskii crested $-3.52 \mathrm{c} / \mathrm{ha}(+11.4 \%)$. The standard variety Chishminskii crested 6 had $3.16 \mathrm{c} /$ ha, the average yield for 3 years. The correlation analysis of the yield structure revealed varieties with high tilling capacity, a strong ear and large seeds (Batyr, Brodskii crested, Parkway) for further study.

\section{References}

1. V.M. Kosolapov, S.V. Pilipko, Fodder production, 3, (2017) (in Russian)

2. S. Fournel, J.H. Palacios, R. Morissette, J. Villeneuve, S. Godbout, M. Heitz, P. Savoie, $141(2015)$ 
3. G.W. Burton, Amer. Soc. Agron. Jour, 39 (1947)

4. M W. Evans, U.S. Dept. Agr. Yearbook. (1937)

5. N.G. Andreev, Meadow and field forage production, (Agropromizdat Publ., 1989) (in Russian)

6. A.A. Nizaeva, R.A. Biktimirov, Proceedings of the Ufa Scientific Center of the Russian Academy of Sciences, 3(6) (2018) (in Russian)

7. S.S. Shain, B.A. Karunin, Wheatgrass (Sel"skokhoziaistvennaia literature Publ., 1950) (in Russian)

8. A.A. Nizaeva, R.L. Akchurin, A.Kh. Shakirzyanov, R.A. Biktimirov, Achievements of science and technology in agriculture, 11 (2019) (in Russian)

9. I.L. Didenko, V.B. Limanskaia, V.I. Buiankin, Agricultural scientific journal, (2016) (in Russian)

10. N.A. Feoktistova, Yu.E. Leonidov, The science age, 24 (2020) (in Russian)

11. B. Dyulgerova, D. Dimova, D. Valcheva, Bulgarian Journal of Agricultural Science, (2016) 